\title{
Analysis of the sexual behavior of elderly women treated at a gynecological outpatient clinic
}

\section{Abstract}

Objective: to analyze the sexual behavior of the elderly women treated at the gynecological outpatient clinic over a period of one year, estimating the proportion of sexually active women, those with an interest in sex, and those who considered the activity of sex important for quality of life, among other findings. Method: a cross-sectional, descriptive, and exploratory study was performed. A pilot study was carried out in order to adjust and validate the data collection instrument. A convenience sample of 100 women was considered for the evaluation of socio-demographic characteristics and sexual behavior, including questions relating to sexual practice and interfering factors. The data were analyzed using frequencies and percentages, and the associations were verified by Pearson's Chi-squared test, considering a significance of $5 \%$. Results: it was observed that $60.0 \%$ of the elderly women felt sexual desire, although $26.0 \%$ were sexually active. While $75.5 \%$ reported that aging does not improve the quality of sex, $83.0 \%$ believed that it is important for quality of life and $78.0 \%$ affirmed that there is no age limit for sexual activity. The cultural view of the elderly may interfere with the maintenance of a sexual life, since $51.0 \%$ reported feeling sexual prejudice due to their age. Conclusion: sexuality is directly related to the perception of quality of life and as it is a vital human function, can interfere in the social, professional, physical and psychic performance of the individual. The practice of and the desire for sex are not extinguished with aging, which contradicts the myth that the elderly person is an asexual being.

\footnotetext{
Santa Casa de Misericórdia, Departamento de Ginecologia e Obstetrícia, Programa de Residência Médica. Vitória, Espírito Santo, Brasil.

2 Santa Casa de Misericórdia, Programa de Pós-graduação em Geriatria. Vitória, Espírito Santo, Brasil.
}

\author{
Luara Ramos Rodrigues' \\ Patrícia Portilho ${ }^{1}$ \\ Alessandra Tieppo² \\ Antônio Chambo Filho'
}

Keywords: Sexuality. Elderly. Aging. 


\section{INTRODUCTION}

The global population has undergone an increase in life expectancy. A number of health issues have therefore emerged, including the need to maintain quality of life, which encompasses the perception of sexuality as a fundamental element, as it involves physical, psychological and social domains ${ }^{1}$. This subject, however, is still seen as taboo ${ }^{2,3}$.

The elderly suffer numerous cultural repressions and prejudices, but the issue is even more pronounced when dealing with sexuality ${ }^{4,5}$. While society designates elderly persons as incapable of exercising their sexuality, sexual desire remains present in all phases of life $\mathrm{fe}^{6,7}$. Although the aging process involves physical, biochemical and functional changes that may influence the reduction of sexual activity, many elderly persons maintain a notable interest in sex with advancing age, refuting social prejudice ${ }^{8}$. It should be remembered that there are several ways of exercising sexuality, such as touch, hugging or caressing ${ }^{7}$. The range of possible interactions accept that the need to attract another person may be more related to the need to live together than the sexual act ${ }^{8}$. Thus, the elderly can exercise their sexuality for longer and with greater satisfaction, strengthening their self-esteem, confidence and improving their quality of life.

A gynecological consultation deals with intimate matters and regions, involving modesty. Doctors could take advantage of this opportunity to approach subjects related to sexuality, the psychosocial environment of the elderly woman and possible diagnoses of changes that hinder the sexual act. The present study can contribute to spreading knowledge about the need for such an approach due to the sexual perception of these patients. It should be emphasized that sexuality is not restricted to an isolated action of the genitals, but constitutes a biopsychosocial process, making it necessary to understand patients in their totality and complexity in order to better address and aid their well-being ${ }^{10,11}$.

The objective of the present study was to evaluate the sexual behavior of elderly patients receiving care at a gynecology outpatient clinic, identifying factors that interfere with sexual satisfaction and practice, estimating, among other findings, the proportion of sexually active individuals, those with an interest in sex and those who consider sex important for quality of life.

\section{METHOD}

A cross-sectional, descriptive and exploratory study of a quantitative nature was carried out between May 2017 and April 2018, approved by the Plataforma Brasil (Brazil Platform) under No. 2142370. The study participants were informed about the research and signed a free and informed consent form (FICF) as a guarantee of the confidentiality and privacy of the responses.

The sample calculation was performed in G*Power to verify the association between the presence of desire and the perception of sex, considering a $95 \%$ confidence level, a power of $85 \%$, an effect size of 0.3 and one degree of freedom. The sample size was 100 patients. The sample was selected without distinction of race and socioeconomic status, considering as inclusion criteria female patients, aged 60 years or older, who spontaneously sought the general gynecology outpatient clinic of the Hospital Santa Casa de Misericórdia in Vitória, Espírito Santo. Patients treated for neoplasia, neuropsychiatric disorders and bedridden elderly women were excluded.

A questionnaire, based on a review of literature, was used as a data collection instrument, composed of structured questions about sexual activity, presence of sexual desire and interest, comorbidities and the perception of quality of life in relation to sex ${ }^{7}$. For the validation and identification of possible confounding factors or poor understanding, a pilot study was performed with 20 patients, the data of which were disregarded in the final study. The data collection instrument was also evaluated and assessed by five gynecologists, in order to verify the relevance of the items for the evaluation of sexual behavior. The final version of the validated, unpublished instrument was applied in a private setting, a doctor's surgery, guided by a single attending gynecologist, who was one of the researchers involved in the study. 
The data were initially analyzed by descriptive statistics such as frequencies and percentages. Associations between the categorical variables were verified using the Pearson chi-squared test, considering a level of significance of $5 \%$.

\section{RESULTS AND DISCUSSION}

A prevalence of married women with complete primary education, who were catholic and suffered from comorbidities, was identified (Table 1).

Table 1. Sociodemographic characteristics of patients (N=100). Vitória, Espirito Santo, 2018.

\begin{tabular}{lll}
\hline Characteristics & $\mathrm{N}$ & $\%$ \\
\hline Marital status & 36 & 36.0 \\
Married & 31 & 31.0 \\
Widow & 19 & 19.0 \\
Divorced & 13 & 13.0 \\
Single & 1 & 1.0 \\
Others & & \\
Education & 14 & 14.0 \\
Illiterate & 69 & 69.0 \\
Elementary School & 14 & 14.0 \\
High school & 3 & 3.0 \\
University & & \\
\hline Religion & 51 & 51.0 \\
Catholic & 46 & 46.0 \\
Evangelical & 2 & 2.0 \\
Others & 1 & 1.0 \\
Atheist & & \\
Comorbidities & 78 & 78.0 \\
Yes & 22 & 22.0 \\
No & &
\end{tabular}

Most of the patients studied were sexually inactive ( $74.0 \%$ ), while $40.5 \%$ said they would like to change this situation, demonstrating that sexual interest is preserved with age. Of the 26 patients who had sex, $61.5 \%$ said they were satisfied with the quality of their relationships, demonstrating that this can be an important factor in the life of the patients' ${ }^{9}$. In contrast to what was imagined, in view of taboos about the sexuality of elderly women, it was observed that $60.0 \%$ of the elderly women felt sexual desire (Table 2).

While $75.5 \%$ said that advancing age does not improve the quality of sex, the results of this study revealed that sexuality is a fundamental element for a good quality of life in old age, with $83.0 \%$ of patients corroborating this hypothesis, In addition,
$78.0 \%$ believed that there is no age limit by which sexual relations should end, contrary to the view that sexuality is incompatible with the advancing age?

Of the interviewees, $78.0 \%$ suffered from comorbidities and $64.4 \%$ reported that their partners had a factor that limits sexual activity, such as a lack of desire, physical limitation and sexual impotence. Physiologically or as a result of diseases and the use of medication, it is expected that there will be an overall reduction in sexual practice when compared to non-elderly patients ${ }^{12}$, but the increase in life expectancy and medical contributions have facilitated the multidisciplinary treatment of comorbidities, dysfunctions and changes that hinder sexual practice ${ }^{11}$. 
It was observed that due to these difficulties the elderly approach sexuality through different forms of penetration, obtaining satisfaction through other actions. Although $58.0 \%$ of the patients affirmed that sexual intercourse depends on penetration, other forms of sexuality were also considered, such as autoeroticism $(24.0 \%)$ and touching and kissing (41.0\%), often allowing an active sexual life to be maintained irrespective of physical limitations or comorbidities ${ }^{7}$. Additionally, the presence of a romantic partner may be associated with increased sexual activity $^{13}$. Sexuality goes beyond sex, companionship in this phase of life reveals important facets such as the existence of feelings, love, respect and complicity?.

In order to understand sexuality among the elderly it is necessary to consider several factors, such as culture, education and the social environment in which it is inserted ${ }^{7}$. Some of these factors, which influence the maintenance or fullness of sexual life, were reported, such as body changes (37.1\%), lack of privacy $(11.3 \%)$, feelings of guilt $(7.2 \%)$, anxiety $2 \%$, and especially the cultural view of the elderly, as $51.0 \%$ affirmed that they feel they are victims of sexual prejudice due to age, and because they feel less valued.

Even though $63.0 \%$ said they are not ashamed of talking about sex and $81.0 \%$ believed that medicine can help improve their sexual relationships, only $25.0 \%$ talked about the subject with their doctor.
Patients experience great difficulty when approaching the subject ${ }^{14,15}$, a fact that should serve as an incentive for improvements in the physician-patient relationship during consultations, a better medical approach and consequent better care for the reported problems.

There was an association between the presence of desire and some factors of sexual perception (Table 3). It was observed that most patients continued to feel sexual desire. Of the sexually active, $80.8 \%$ still felt sexual desire, but unfortunately, due to a lack of knowledge and cultural pressure, many such elderly people also experience feelings of guilt or shame for simply perceiving themselves to have the desire to seek pleasure ${ }^{16}$.

There was a greater proportion of women who believed that sex improves quality of life and who continued to feel sexual desire (68.7\%). The results point out that sexuality is an important factor for a good quality of life in old age, making an understanding of how the elderly perceive and experience the same essential ${ }^{16}$.

From this perspective, the potential effects of sexual experiences are also recognized. Of the patients who believed that they have had an orgasm, the majority still felt desire $(70.7 \%)$ as well as those who believed the quality of sex improved with age $(79.2 \%)$ and that there is no age limit for the end of sexual intercourse.

Table 2. Characteristics of sexual behaviour of patients $(\mathrm{N}=100)$. Vitória, Espirito Santo, 2018.

\begin{tabular}{llll}
\hline Sexual Behavior & & $\mathrm{n}$ & $\%$ \\
\hline Do you still have sexual relations? & Yes & 26 & 26.0 \\
& No & 74 & 74.0 \\
\hline If you answered no, would you like to have such relations? & No & 44 & 59.5 \\
& Yes & 30 & 40.5 \\
\hline Are you satisfied with the quality of the sexual intercourse you have? & No & 10 & 38.5 \\
& Yes & 16 & 61.5 \\
\hline Do you feel sexual desire? & No & 40 & 40.0 \\
& Yes & 60 & 60.0 \\
\hline Are you ashamed to talk about sex? & No & 63 & 63.0 \\
& Yes & 37 & 37.0 \\
\hline Do you think you have ever had an orgasm? & No & 25 & 25.0 \\
& Yes & 75 & 75.0 \\
\hline Do you believe that sex is important for quality of life? & No & 17 & 17.0 \\
& Yes & 83 & 83.0 \\
\hline
\end{tabular}


Continuation of Table 2

\begin{tabular}{|c|c|c|c|}
\hline Sexual Behavior & & $\mathrm{n}$ & $\%$ \\
\hline \multirow[t]{2}{*}{ Do you believe there is an age limit for the end of sexual relations? } & No & 78 & 78.0 \\
\hline & Yes & 22 & 22.0 \\
\hline \multirow[t]{2}{*}{ Do you believe that increasing age improves the quality of sex? } & No & 74 & 75.5 \\
\hline & Yes & 24 & 24.5 \\
\hline \multirow[t]{2}{*}{ Do you feel a victim of sexual prejudice due to age? } & No & 49 & 49.0 \\
\hline & Yes & 51 & 51.0 \\
\hline \multirow[t]{2}{*}{ Do you believe that medicine can help improve sex? } & No & 19 & 19.0 \\
\hline & Yes & 81 & 81.0 \\
\hline \multirow[t]{2}{*}{ Have you talked to your doctor about this? } & No & 75 & 75.0 \\
\hline & Yes & 25 & 25.0 \\
\hline \multirow[t]{3}{*}{ As you get older, how do you feel? } & More valued & 39 & 39.0 \\
\hline & Less valued & 48 & 48.0 \\
\hline & Do not know & 13 & 13.0 \\
\hline \multirow[t]{6}{*}{ Factors that interfere with sexual practice } & Body & 36 & 37.1 \\
\hline & Anxiety & 5 & 5.2 \\
\hline & Privacy & 11 & 11.3 \\
\hline & Guilt & 7 & 7.2 \\
\hline & None & 22 & 22.7 \\
\hline & Others & 36 & 37.1 \\
\hline \multirow[t]{4}{*}{ Does your partner have any limitations with regard to sex? } & Impotence & 16 & 35.6 \\
\hline & Lack of desire & 5 & 11.1 \\
\hline & Physical limitation & 8 & 17.8 \\
\hline & No & 16 & 35.6 \\
\hline \multirow[t]{3}{*}{ Perception of sexual act } & Masturbation & 24 & 24.0 \\
\hline & Depends on penetration & 58 & 58.0 \\
\hline & $\begin{array}{l}\text { Doesn't depend on } \\
\text { penetration (touching, } \\
\text { kissing ...) }\end{array}$ & 41 & 41.0 \\
\hline
\end{tabular}

Table 3. Association between the presence of desire and sexual perception. Vitória, Espirito Santo, 2018.

\begin{tabular}{|c|c|c|c|c|c|}
\hline \multirow[t]{3}{*}{ Sexual perception } & \multicolumn{5}{|c|}{ Presence of sexual desire } \\
\hline & \multicolumn{2}{|l|}{ No } & \multicolumn{3}{|c|}{ Yes } \\
\hline & $\mathrm{n}$ & $\%$ & $\mathrm{n}$ & $\%$ & $\mathrm{p}$ \\
\hline \multirow[t]{2}{*}{ Do you still have sexual relations? } & 35 & 47.3 & 39 & 52.7 & 0.012 \\
\hline & 5 & 19.2 & 21 & 80.8 & \\
\hline \multirow[t]{2}{*}{ Do you think you have ever had an orgasm? } & 18 & 72.0 & 7 & 28.0 & 0.000 \\
\hline & 22 & 29.3 & 53 & 70.7 & \\
\hline \multirow{2}{*}{$\begin{array}{l}\text { Do you believe there is an age limit for } \\
\text { the end of sexual relations? }\end{array}$} & 26 & 33.3 & 52 & 66.7 & 0.010 \\
\hline & 14 & 63.6 & 8 & 36.4 & \\
\hline \multirow{2}{*}{$\begin{array}{l}\text { Do you believe that increasing age improves } \\
\text { the quality of sex? }\end{array}$} & 34 & 45.9 & 40 & 54.1 & 0.029 \\
\hline & 5 & 20.8 & 19 & 79.2 & \\
\hline \multirow{2}{*}{$\begin{array}{l}\text { Do you believe that sex is important } \\
\text { for quality of life? }\end{array}$} & 14 & 82.4 & 3 & 17.6 & 0.000 \\
\hline & 26 & 31.3 & 57 & 68.7 & \\
\hline
\end{tabular}


It is not intended that the results presented here will end this discussion. The data should not be generalized, as the results and conclusions of the present study may not be related to other populations due to the sample. This study presupposes the reality of the subject within the context of the health of the elderly and encourages the carrying out of further research and the validation of instruments that involve all aspects of the sexuality of the individual.

\section{CONCLUSION}

Sexuality is directly related to the perception of quality of life, which is a broad concept that contemplates not only the health situation of the elderly person, but also their image in terms of physical, psychological and social aspects. Sexual practice is not extinguished with aging, countering the myth that the elderly person is an asexual being.

Most of the patients studied were sexually inactive, but would like to change this situation, reflecting the permanence of sexual interest despite advancing age. However, factors that cause the overall reduction of sexual practice were identified, such as the presence of comorbidities, bodily changes, sexual impotence, and a distorted social view of sexuality, making the elderly feel ill at ease or even guilty when expressing their desires. Despite this, it was observed that the

\section{REFERENCES}

1. Castro e Silva IM, Andrade KL. Avaliação da qualidade de vida de idosos atendidos em um ambulatório de Geriatria da região nordeste do Brasil. Rev Bras Clin Med. 2013;11(2):129-34.

2. Moura I, Leite MT, Hildebrandt LM. Idosos e sua percepção acerca da sexualidade na velhice. Rev Bras Ciênc Envelhec Hum. 2008;5(2):132-40.

3. Viana HB, Madruga VA, Guirardello EB, Silva D. Adaptação e validação da ASKAS - Aging Sexual Knowledge and Attitudes Scale em idosos brasileiros. Rev Kairós. 2012;15(8):99-125.

4. Vieira KFL, Nóbrega RPM, Arruda MVS, Veiga PMM. Representação social das relações sexuais: um estudo transgeracional entre mulheres. Psicol Ciênc Prof. 2016;36(2):329-40. patients find other ways to obtain satisfaction and that cultural prejudice in relation to sex and age was not observed among the elderly themselves, the majority of whom said they believed that there is no age limit for the end of sexual practice.

Studies that explore and identify the factors involved and the difficulties encountered by these patients make a fundamental contribution to the integral care of the patient. Although this subject is considered of great importance to the lives of people of all ages, Brazilian studies on the theme are scarce. Greater knowledge of this subject is increasingly necessary, as a revolution has been taking place in the practice of sexuality, with an indisputable effect on the elderly.

Further studies on the subject are therefore important, improving the field of geriatrics/ gerontology and facilitating the doctor-patient relationship, which is an opportune moment for the providing of quality information and, if necessary, the treatment of specific dysfunctions. Psychosocial support and the planning of public health actions are also important to ensure greater discussion of the topic and the demystification of the sexuality of the elderly, bestowing the subject with a naturalness which will have repercussions on the well-being and quality of life of the patient.

5. Souza M, Marcon SS, Bueno SMV, Carreira L, Baldissera VDA. A vivência da sexualidade por idosas viúvas e suas percepções quanto à opinião dos familiares a respeito. Saúde Soc. 2015;24(3):936-44.

6. Laurentino NRS, Barboza D, Chaves G, Besutti J, Bervian AS, et al. Namoro na terceira idade e o processo de ser saudável na velhice: recorte ilustrativo de um grupo de mulheres. Rev Bras Ciênc Envelhec Hum. 2006;3(1):51-63.

7. Alencar LD, Marques APO, Leal MCC, Vieira JCM. Exercício da sexualidade em pessoas idosas e os fatores relacionados. Rev Bras Geriatr Gerontol. 2016;19(5):861-9. 
8. Bastos CC, Closs VE, Pereira AMVB, Batista C, Idalêncio FA, de Carli GA, et al. Importância atribuída ao sexo por idosos do município de Porto Alegre e associação com a autopercepção de saúde e o sentimento de felicidade. Rev Bras Geriatr Gerontol. 2012;15(1):87-95.

9. Dantas TWSS, Silva AS, Farias AM. "Toda idade tem prazer e medo": idoso e sexualidade [Internet]. In: Anais do $5^{\circ}$ Congresso Internacional de Envelhecimento Humano; 22-24 nov. 2017; Maceió. Maceió: Realize; 2017 [acesso em 21 ago. 2018]. Disponível em: http://www.editorarealize.com.br/ revistas/cieh/trabalhos/TRABALHO_EV075_ MD2_SA9_ID1779_23102017155946.pdf

10. Alencar DL, Marques APO, Leal MCC, Vieira JCM. Fatores que interferem na sexualidade de idosos: uma revisão integrativa. Ciênc Saúde Colet. 2014;19(8):3533-42.

11. Hughes AK, Rostant OS, Pelon S. Sexual problems among older women by age and race. J Womens Health. 2015;24:663-9.

Received: May 08, 2018

Reviewed: September 17, 2018

Accepted: Septemper 20, 2018
12. Appa AA,Creasman J, Brown JS, Van Den Eeden SK,Thom DH, Subak LL, et al. The impact of multimorbidity on sexual function in middle-aged and older women: beyond the single disease perspective. J Sex Med. 2014;11(11):2744-55.

13. Thomas HN, Hess R,Thurston RC. Correlates of sexual activity and satisfaction in midlife and older women. Ann Fam Med. 2015;13(4):336-42.

14. Olatayo AA, Zubwa OO, Adekunle AE. Sexuality in Nigerian older adults. Pan Afr Med J. 2015;22:315.

15. Uchôa YS, Costa DCA, Silva Junior IAP, Silva STS, Freitas WMTM, Soares SCS. A sexualidade sob o olhar da pessoa idosa. Rev Bras Geriatr Gerontol. 2016;19(6):939-49.

16. Vieira KFL, Coutinho MPL, Saraiva ERA. A Sexualidade na velhice: representações sociais de idosos frequentadores de um grupo de convivência. Psicol Ciênc Prof. 2016;36(1):196-209. 